\title{
DIVINE LOVE AND THE ARGUMENT FROM DIVINE HIDDENNESS
}

\author{
EBRAHIM AZADEGAN \\ Sharif University of Technology, Teheran
}

\begin{abstract}
This paper criticizes one of the premises of Schellenberg's atheistic argument from divine hiddenness. This premise, which can be considered as the foundation of his proposed argument, is based on a specific interpretation of divine love as eros. In this paper I first categorize several concepts of divine love under two main categories, eros and agape; I then answer some main objections to the ascription of eros to God; and in the last part I show that neither on a reading of divine love as agape nor as eros can Schellenberg's argument be construed as sound. My aim is to show that even if - contra Nygren for example we accept that divine love can be interpreted as eros, Schellenberg's argument still doesn't work
\end{abstract}

\section{THE ARGUMENT FROM DIVINE HIDDENNESS}

Many people are perplexed that God should permit a situation in which many human beings live in incomprehension and bewilderment regarding His existence, while all the time He could save humanity from such a predicament. The problem of 'divine hiddenness' refers to the problem for the theist in holding that we human beings live in a world in which we have limited cognitive faculties; knowledge of God is essential for our flourishing in this-worldly and otherworldly life; and where, in addition, God, the omniscient, omnipotent, and perfectly loving, has permitted us to live in this bewilderment and perplexity regarding His attributes and existence, all the while knowing that it is essential for our well-being. 
More than anyone else, John Schellenberg is responsible for renewing and framing the contemporary debate about divine hiddenness. ${ }^{1}$ Roughly speaking, he sees the fact that there are some non-resistant non-believers as being incompatible with the existence of a perfectly loving God.

The final version of his argument is as follows:

(1) Necessarily, if God exists, anyone who is (i) not resisting God and (ii) capable of meaningful conscious relationship with God is also (iii) in a position to participate in such relationship (able to do so just by trying).

(2) Necessarily, one is at a time in a position to participate in meaningful conscious relationship with God only if at that time one believes that God exists.

(3) Thus (from 1 and 2), necessarily, if God exists, anyone who is (i) not resisting God and (ii) capable of meaningful conscious relationship with God also (iii) believes that God exists.

(4) There are (and often have been) people who are (i) not resisting God and (ii) capable of meaningful conscious relationship with God without also (iii) believing that God exists.

(5) Thus (from conjunction of 3 and 4) God does not exist. ${ }^{2}$

Premise 1 of his argument is the most important premise, and of course requires a separate argument. To support premise 1 Schellenberg argues that if God is loving, He seeks an explicit reciprocal relationship with us, involving not only such things as divine guidance, support, and forgiveness, but also what leads to the faith, trust, obedience, and worship that would contribute to human well-being. He therefore concludes that if God seeks a reciprocal relationship, then for any human person $\mathrm{H}$ at any time $t$, if $\mathrm{H}$ is at $t$ capable of relating personally with God, $\mathrm{H}$ at $t$ is in a position to do so just by choosing.

\footnotetext{
${ }^{1}$ Schellenberg's main discussions of this subject can be found in John L. Schellenberg, Divine Hiddenness and Human Reason (Ithaca: Cornell University Press, 1993), and 'What the Hiddenness of God Reveals: A Collaborative Discussion', in Divine Hiddenness: New Essays, ed. D. Howard-Snyder and P.K. Moser (Cambridge: Cambridge University Press, 2002), pp. 33-61. He responds to several objections to his argument in 'The Hiddenness Argument Revisited (I)', Religious Studies, 41 (2005), 201-15, and 'The Hiddenness Argument Revisited (II)', Religious Studies, 41 (2005), 287-303. For his recent and most developed version of the argument see his The Wisdom to Doubt (Ithaca: Cornell University Press, 2007), Chaps. 9 and 10.
}

${ }^{2}$ Schellenberg The Wisdom to Doubt, pp. 204-206. 
In this paper I focus on the notion of the capability of a person to be the object of divine love and to engage in personal relational love with God in order to show that Schellenberg has incorrect expectations of divine love and the human-divine relationship. He has dismissed the vital role that God expects us (human beings) to play in our relationship with God. In this regard, I shall try to answer the following three questions:

(1) What type of love is required in order for us to have a personal reciprocal relationship with God?

(2) Is it legitimate to ascribe this type of love to God? And under what conditions?

(3) If it is legitimate to ascribe to God a type of love that requires a personal reciprocal relationship, then what would be the conditions of the object of this type of love? In other words, who is capable of being in the reciprocal love relationship with God?

The paper is organized as follows. First, I shall briefly explain different concepts of divine love, and then I shall show that, drawing from Nygren's account, one can distinguish two categories of divine love: eros and agape. ${ }^{3}$ I shall show that eros, but not agape, as divine love, requires a personal reciprocal relationship and union with God. Then I shall answer some of the main objections to attributing eros to God, namely the Aristotelian and Platonic objections. Finally, I shall interpret Schellenberg's argument according to both types of divine love (eros and agape) in order to show that in neither of these forms is his first premise compelling, because agape does not require a reciprocal relationship and eros requires a high standard of capability for the object of love, which normal human beings lack unless they make sufficient efforts to obtain it. In other words, merely being non-resistant to God is not enough.

${ }^{3}$ Anders Nygren, Agape and Eros, trans. Philip S. Watson (London: Society for Promoting Christian Knowledge [SPCK], 1982). It is worth noting that Nygren here distinguishes three types of divine love: eros (the Hellenistic concept of divine love), nomos (the Old Testament concept of divine love), and agape (the truly Christian concept of divine love). He tries to show that both eros and nomos require some special capabilities and admirable values on the part of the object of love, while agape is a type of God's love that cannot be contained within the framework of the Law (like nomos), and is not justified on the ground of merit (like eros), but is based on free grace and groundless, spontaneous, and unmotivated divine love. In this paper I use the important difference between eros and agape to construct an objection to Schellenberg's argument; I think that nomos can be regarded as a token of the eros-type of divine love, broadly speaking because it is based on a sort of value inherent in the object of love as well. 


\section{DIVINE LOVE}

It is not surprising that Schellenberg constructs his argument based on certain expectations that people may have of a loving God given the immense importance of this subject in the Christian tradition. So essential to Christianity is the notion of divine love that it seems no exaggeration to describe it as the heart of the Christian faith. 'God is love and whoever lives in love lives in God, and God in them." These words, from the first letter of John, powerfully express the Christian image of the relationship between God and humanity. In the same chapter, John also offers a kind of summary of the Christian concept of the human-human relationship on that basis: 'Dear friends, let us love one another, for love comes from God. Everyone who loves has been born of God and knows God. Whoever does not love does not know God, because God is love. ${ }^{35}$

The claim that God is love can be interpreted in at least two different ways. It can be regarded as expressing the idea that (a) God is the source or origin of love from which all lovers derive their love; love is a gift from God to human beings, and God causes, gives and inspires love in us, but 'lover' is not a proper attribute of God, or (b) God Himself is the one who loves and He loves us, as well. ${ }^{6}$ The first interpretation is not our concern here because it deals with the cause of human beings' love towards God or other beings, while here we are dealing with God's love toward human beings.

The New Testament word for God's generous love is 'agape'. This comes from the Greek translation of the Hebrew word 'ahaba' in the Song of Songs, and subsequently became a typical expression for the Biblical notion of love. The term 'agape' refers to God's love for all humans and all creatures regardless of their righteousness or depravity. Agape is God's disinterested love; God loves in an agapeic manner because of His nature, for He is essentially loving - for He is love. It is not the case that love is merely one of the activities of God, such that God might act lovingly in some cases and not in others; rather, love is the essential activity of God, in the sense that all of His actions should be interpreted according to His love. Every activity of God is loving activity, and all His relations with men are characterized by His love. God loves, in the sense of agape,

\footnotetext{
${ }^{4}$ I John 4: 16.

${ }^{5}$ I John 4: 7-8.

6 For more details on these interpretations and the relation between them, see Catherine Osborne, Eros Unveiled (Oxford: Clarendon Press, 1996), pp. 41-5.
} 
all of His creatures, indifferent to their goodness or badness. ${ }^{7}$ Agape is generous, spontaneous, and unmotivated love for all creatures.

However, many believe that we can also ascribe what some have called an 'acquisitive' type of love to God; ${ }^{8} \mathrm{I}$ shall use the familiar historic term 'eros' to refer to this type of divine love, by drawing a contrast with the other type of divine love that is generous and unconditional. Historically, the word 'eros' refers to attentive, mutual, reciprocal (that is: seeking reciprocity), and even indulgent or egocentric love. The term comes from the ancient Greek notion of erotic love, in which a man longs to acquire what is valuable in his eyes, something that he does not possess but desires to have. Eros, so defined, as the desire for union with the beloved, is egocentric love and is rooted in our needs and weakness. It seems that eros is a result of valuing and appreciating what the lover already lacks or needs. ${ }^{9}$

Based on this narrow interpretation, eros could potentially include a defective element - and, indeed, because of the distinctively human flaws that undergird it, Nygren explains that the notion of divine love cannot possibly be interpreted in the sense of eros. On a properly Christian conception, he contends, agape is the only acceptable interpretation of God's love towards His creatures. ${ }^{10}$

Nygren goes further than criticizing the idea that divine love be considered as eros: he also proposes that should the human desire for union with God be interpreted in such a manner, it would be infected with egocentricity. Such an interpretation, he maintains, should therefore

${ }^{7}$ See Nygren, Agape and Eros, pp. 108-117.

${ }^{8}$ It seems noteworthy that if we try to place God and humanity in a relationship of love where God is the lover and humanity the beloved, we are likely to start by comparing the two in terms of superiority and inferiority, or bestowal and reception. It seems that there is nothing that we, as humans, can be in a position to supply for God; nor is there anything that we have which is not bestowed by God. So, if we accept the dichotomy between acquisitive and generous love, we might find ourselves committed to the conclusion that since God is perfect and merciful, His love could only be 'generous'; and, conversely, our love toward God can only be 'acquisitive'. In this paper I am concerned with the dichotomy between these two different types of love: the acquisitive (eros) and generous (agape) types of love. In due course I shall refer to some of the proponents of the 'acquisitive' interpretation of God's love.

${ }^{9}$ Nygren, Agape and Eros, pp. 158-182.

${ }^{10}$ For more on this dichotomy and the concept of divine love in other monotheistic traditions, see Benyamin Abrahamov, Divine Love in Islamic Mysticism: The Teachings of al-Ghazâlî and al-Dabbâgh (London: Routledge, 2011), ch. 1. 
be dismissed. On this basis, Nygren criticizes all kinds of Gnostic and mystical practices from the history of religion, claiming that they are ill-formed. ${ }^{11}$ Agape, he emphasizes, is the only sense in which the New Testament concept of love can be interpreted.

However, on the basis of an examination of all the uses of the word 'agape' in the New Testament and early Christian texts, Catherine Osborne tries to show that in many cases divine love can be interpreted as eros. She criticizes Nygren's concept of the pure Christian concept of love, showing how the authors of the New Testament were influenced by Greek and Hebrew terminology and background knowledge inherited along with it. ${ }^{12}$

The possibility that Christian Scripture provides a basis for interpreting divine love as both eros and agape is also raised by Alvin Plantinga. ${ }^{13} \mathrm{He}$ emphasizes that there are some scriptural images that permit us to ascribe eros to God, and that his love is not exclusively agapeic. He argues that Scripture presents this kind of divine eros as existing within the subjects of the Trinity, especially Jesus. Plantinga cites Isaiah 62: 5: 'As a bridegroom rejoices over his bride God rejoices over you.' ${ }^{14}$ The bridegroom rejoicing over his bride does not love her with a merely agapeic love, Plantinga explains: 'He desires and longs for something outside himself, namely union with His beloved.' ${ }^{15}$

Despite these theological responses, I think Nygren's objections to attributing eros to God are worthy of further philosophical investigation. To reach a better understanding of how eros can be attributed to God we shall scrutinize the notion of eros, its roots, the definition of it, and the criterion under which it can be attributed to God. The first questions that should be addressed in this regard are: How can eros, whose ultimate aim is the union with the beloved, be attributed to God? And what criteria would something have to meet to be an object of eros, if the lover is God? In what follows, I shall explore Aquinas' answer to this question; I shall then try to answer some of the objections to viewing eros as a form of divine love.

${ }^{11}$ Nygren, Agape and Eros, pp. 190-220.

${ }^{12}$ Catherine Osborne, Eros Unveiled, chs. 1 and 2.

${ }^{13}$ Alvin Plantinga, Warranted Christian Belief (Oxford: Oxford University Press, 2000), pp. 311-323.

${ }^{14}$ Isaiah 62:5.

${ }^{15}$ Plantinga, Warranted Christian Belief, p. 320. 
To be clear: what I am going to suggest regarding the sketched dichotomy between the agape and eros interpretations of divine love, is that even if, contra Nygren, we accept that divine love can be interpreted as eros, Schellenberg's argument still doesn't work. If divine love is purely agape, then Schellenberg's argument is in trouble, for God's capacity to love us agapeically is obviously entirely independent of anything about us, including the level of hiddenness or non-hiddenness of God from us. If God's love were purely agape, as Nygren suggests, Schellenberg's argument would fail. But it seems to me that it is plausible to think of God's love as eros in at least some senses. I shall now go on to consider these and show that even if God's love is eros in these senses, Schellenberg's argument still fails.

\section{DIVINE LOVE AIMS AT UNION WITH THE BELOVED}

In addition to the generous type of love that is love for the sake of the beloved regardless of her intrinsic values, Aquinas distinguishes a type of love that aims at union with the beloved when a lover not only wishes some good for the beloved but also loves the relationship with the beloved to whom he wishes good. ${ }^{16}$ For Aquinas, the desire for this love is rooted in the joy of union with the beloved, because 'every lover rejoices at being united to the beloved. ${ }^{17}$ However, Aquinas focuses primarily on the union between man and God as the result of our love towards God. He thinks that the ultimate good for any human person is union with God. ${ }^{18}$ This kind of idea should, in fact, be considered the motivation for various mystical practices in the Christian tradition. However, when we talk about God's desire for union with human beings - and in particular when we attribute eros to God - the idea of union seems problematic. What does it mean to say that God desires union with us? When we understand divine love as agape, and thereby dwell on God's benevolence and His desire for the good of human beings regardless of our goodness or badness (what Aquinas named the simple view of love), there seems to be no problem. Nonetheless, the exact question that I shall pursue is: If it were legitimate to ascribe eros to God, what would be the nature of the union desired and the conditions for bringing it about?

16 ST I-II q.26 a.4 (NY: Cosimo, trans. Fathers of English Dominican Province, 2007, originally published 1912).

17 ST I-II q.70 a.3.

${ }^{18}$ See, for example, ST I-II q.1 a.8. 
As mentioned, Aquinas distinguishes two different sorts of love, the desire for the good of the beloved and the desire for union with the beloved, which in the case of divine love I have classified under the categories of agape and eros respectively. Here I focus on the more problematic part of this account, which interprets the erotic element of divine love as God desiring union with us, human beings.

Reflecting on this form of love, Eleonore Stump explains that two things seem to be required for union between persons: personal presence and mutual closeness. ${ }^{19}$ Personal presence includes not only causal and cognitive contact between the lover and the beloved, but also their conscious awareness of and shared attention to each other. Mutual closeness is what strengthens the required shared attention and mutual awareness, in a sense that the lover and the beloved become completely engaged with each other. Mutual closeness in the case of two persons can hardly be reduced to propinquity or even lively conversational relations: it seems to include sharing thoughts and feelings as well. And not just any thoughts and feelings will do here: as Stump says, 'For Paula to be close to Jerome, Jerome has to share with Paula those thoughts and feelings of his that he cares about and that are revelatory of him. Jerome would not be close to Paula if he shared with her a great many of his most trivial thoughts but nothing of what was important to him or revealing of him. ${ }^{20}$

Suppose, however, that Jerome does reveal enough of his thoughts and feelings to Paula; if Paula does not will to understand Jerome's selfrevelation, or is not able to understand what he is trying to reveal, she will not be close to him. So, mutual closeness requires self-revelation on the part of the lover and the will for reception and the ability of comprehension of the received material on the part of the beloved. ${ }^{21}$

In the case of divine love toward human beings, it seems that according to Theistic religions, God meets both of the conditions for allowing human beings to be in union with Him: God is omnipresent, and has causal relations with and direct and unmediated cognitive access to everything. In addition, God is always and everywhere in a position to pay attention to any creature able and willing to share attention with

19 Eleonore Stump, Wandering in Darkness: Narrative and the Problem of Suffering (Oxford: Oxford University Press, 2010), ch. 6.

${ }^{20}$ Ibid., p. 119.

${ }^{21}$ Ibid. 
Him. God also has self-disclosed Himself to be known by us in revelation and creation. He has revealed certain truths about Himself through His prophets and messengers in history, and has revealed (some truths about) His mind and will to human beings. For these reasons, God has disclosed Himself to fulfil His desire for union with human beings.

But the crucial question that arises is whether God's desire for union with human beings is sufficient for our being in a reciprocal relationship of love and union with God. Contra Schellenberg, my answer is 'No', because, as mentioned, in addition to divine omnipresence and selfdisclosure, union requires three things on the part of the beloved. First, it requires the beloved's attention to God's presence. This I shall term praying: praying seems to be a way in which we can achieve shared attention with God in a way that man wholeheartedly pays attention to God and asks Him for whatever he needs and has a sense that God hears and sees him and pays attention to him. Second, union requires the beloved's will to understand the divine presence in His creatures through His revelations. And third, it requires the beloved's ability to comprehend divine self-disclosure in His revelation. The second and third conditions require thinking and reflection on revelation and Scripture, in addition to continuous repentance for the sins which lead us astray. So it seems that praying, repentance, and reflection on divine revelation are three prerequisites for us to respond to God's eros. These are three conditions which must be met by the beloved man if God's desire for union with him is to be satisfied.

Furthermore, these things may be taken to be a matter of degree. The more a human being becomes purified and sanctified, the stronger the relation of eros he can have with God. How close God becomes to any one person depends on how much that person tries to pray, repent, and be open to the divine free gift. God's grace is free for all of us, but our success in availing ourselves of it depends on us.

In this way, it seems that eros can be attributed to God and yet Schellenberg's argument still not work. What we find, then, through reasoning and consideration of the concept of love in Christianity, is that while every human being is the potential object of God's eros, in fact only meritorious human beings can reach the state of union with their Lord. ${ }^{22}$

22 There is a long-running debate in the literature regarding the notion of divine grace and whether humanity merits the gifts of God. Nevertheless, my contention here is that 
I have argued, then, that whilst it is plausible to consider God's love as eros as well as agape, and thus that the 'quick' way to sidestep Schellenberg's argument (that of simply denying any erotic element in the divine love towards His creatures) is blocked, the sort of erotic element supposed to be present in God's love towards His creatures is nevertheless not sufficient to support Schellenberg. In the next part I shall therefore consider and respond to some Aristotelian and Platonic objections to construing divine love as eros in any sense, in order to shore up my implicit suggestion that the Christian is in fact best advised to allow an element of eros into his or her conception of divine love, rather than simply take the 'quick' way with Schellenberg's argument.

\section{THE PLATONIC OBJECTION TO ATTRIBUTING EROS TO GOD}

As defined, eros involves desire for union with the beloved, and is a matter of longing, perceiving, noting, appreciating, delighting in, and relishing. A primary question then, is: May eros be ascribed to God? As I shall explain, from a Platonic point of view, it seems that eros may hardly be supposed a suitable interpretation of divine love. ${ }^{23}$

Traditionally, every discussion of love - whether celestial, romantic, ascending, or descending love - begins with Plato. His ideas on love are expressed mainly in the Symposium, Lysis, and the Phaedo. While in the Symposium Socrates reports the views of Diotima of Mantinea, a wise woman, philosopher, and mystic, in the two other books Socrates himself is the main interlocutor. In the Symposium Socrates reports his dialogue with Diotima regarding the nature of love and its effects. Diotima, we are told, declares that eros is not a god but at most a daemon or spirit, an intermediary between gods and mortals. According to Plato, Eros is a son of Poros (the symbol of resources, wealth, and possessions) and Penia (the symbol of poverty).

So because Eros is the son of Poros and Penia, his situation is in some such case as this. First of all, he is always poor; and he is far from being

only meritorious human beings are capable of being in union with God, regardless of the way a human being may achieve such a meritorious character, and no matter whether it is itself through grace of God or not.

${ }^{23}$ Catherine Osborne examines this claim in detail and concludes that because Plato intentionally uses direct quotes from Diotima it is better to ascribe this claim to her rather than Plato or Socrates. See Osborne, Eros Unveiled, pp. 86-116. 
tender and beautiful, as many believe, but is tough, squalid, shoeless, and homeless, [...] he has the nature of his mother, always dwelling with neediness. But in accordance with his father he plots to trap the beautiful and the good, and is courageous, stout, [...] desirous of practical wisdom and inventive. ${ }^{24}$

But of course deficiencies and shortages cannot be attributed to God. 'How then could he who is without a share in the beautiful and good things be a god?' Diotima asks; and Socrates replies: 'In no way it seems.'25

From this passage one may conclude that for Plato, eros cannot be an attribute of God. ${ }^{26}$ Following Robert Adams, I will summarize Plato's argument (to the effect that eros is not an attribute of God) as follows: ${ }^{27}$

(1) Eros involves desire for its object.

(2) One desires what one needs and does not have.

(3) Thus, the object of eros is what one needs or lacks.

(4) Eros, especially the gods' eros if they have any, will have things beautiful and good as its object.

(5) God cannot lack such things or be needy in respect of goodness and beauty.

(6) Thus, eros is incompatible with deity.

Adams, responding to Plato's argument, argues that eros can be regarded as a model of divine love concerning finite things. He objects that neediness and desire is not essential to eros because its central feature is valuing, and desire is only one possible expression of valuing. According to Adams, the essential content of eros would be a kind of liking, admiration, and appreciation, and not necessarily the desire or longing that implies the absence of the desirable/longed-for element. Then eros would be a model of the divine love God expresses when He admires and appreciates the good acts and character of His servants. Thus eros can be attributed to God without attributing any deficiency or neediness to Him.

I think this reply to Plato's objection is inconclusive. The 'valueappraisal' account of love, which seems to be what Adams has in mind,

${ }^{24}$ Symposium (Cambridge: Cambridge University Press, trans. Benjamin Jowett, 1980), 203 b-d.

${ }^{25}$ Ibid., 202 c5-d7.

${ }^{26}$ Here it should be noted that eros as an emotion or state of mind takes its name from Eros, the person or a demon. In some phrases these two are used indistinguishably.

27 Robert M. Adams, Finite and Infinite Goods (Oxford: Oxford University Press, 1999), p. 133. 
is just one sort of eros alongside the union account. I agree with Adams that we can ascribe the value-appraisal type of eros to God, because it is certain that God admires and appreciates good and admirable beings. However, if this was all that there is to God's erotic love, eros as divine love toward human beings reduces to God's appreciation of good human characters and attributes. And consequently the objects of divine eros are only those creatures who instantiate these virtues, for they alone are worthy of God's appreciation and admiration. It seems that God may be pictured as having the desire for being in union with all of us, independently of whether or not and to what extent He appreciates us.

Perhaps we can respond to Plato's objection in a different way, by examining the relation between neediness and desire. We can, perhaps, distinguish between two kinds of desire: one may desire something as a means to one's own ends (as a sort of neediness); or one may desire something as a means to the beloved's end. ${ }^{28}$ It is in the second sense that we should understand God's desire for union with human beings. If, as Aquinas proposes, the goal of human creation is union with God, then it seems plausible that the benevolent God also desires that we achieve this union with Him. In this case it is not required to ascribe any neediness to God. Although it is true that needs and desires are commonly associated, they are nonetheless not correlative. It is possible to need something (for example, a reform in one's eating habits) without desiring it; but it is also possible to desire something only for the fulfilment of the desire for the good of the object of desire (for example, that those one hears on the news are suffering from famine in a faraway country receive food).

There is another objection to the attribution of eros to God, however, this one based on ideas from Aristotle. In the following section I shall examine this objection.

\section{THE ARISTOTELIAN OBJECTION TO DIVINE LOVE FOR US}

Aristotle seems to have thought of God as so absorbed in selfcontemplation as to have no concern for lesser beings. ${ }^{29}$ For Aristotle, God's self-contemplation and self-love is the origin of creation of other

${ }^{28}$ There may also be a type of desire without caring about the end of desire - desire for the sake of desire itself. But it seems eccentric to attribute this to God.

${ }^{29}$ This is a common interpretation of Book Lambda of his Metaphysics (Penguin Classics, trans. Hough Lawson-Tancred, 1999), 1074b15-1075a11. 
beings. But are we to understand his view as the view that God is so absorbed in self-contemplation and self-love that He has no concern or thought at all for lesser beings? Why should divine self-contemplation block God from bestowing attention and love on other creatures? It seems that we have no reason to conclude from the Aristotelian arguments that, while God always engages in self-contemplation, He cannot pay attention to other beings.

The proponent of the Aristotelian argument can improve his objection, however, by saying that what blocks God from desiring union with lesser beings is the possibility of vulnerability, which is associated with love. God would put Himself at risk if He came to love other beings. Vulnerability and risk are associated with the sort of desire the satisfaction of which is to some extent out of the control of the lover. Insofar as the fulfilment of God's desire to be in union with human beings is at least in part within human beings' control, God's having a desire for union with us makes God vulnerable to us. But, the objection continues, God is self-sufficient and sovereign, and thus nothing that matters to God is dependent on anything human beings do. Therefore, it is not possible to attribute eros to God, at least in the sense that eros includes God's desire for union with us. ${ }^{30}$

I think this objection is not yet compelling. It seems plausible that the sovereign God can freely choose to create a creature that has free will, and that the existence of creatures with free will then necessitates their having free choices and actions. Thus far, their free actions seem not to be in contradiction with divine sovereignty; however, if God desires that the free creatures freely choose something that is good for them, then this divine desire does indeed makes God vulnerable to their actions. It seems true then that God, if He desires union with us, is vulnerable to our actions; but this can hardly be considered as incompatible with divine sovereignty; it was His free choice to create free creatures in the first place and at any stage, should He so choose, He could remove their freedom. At least this much seems to be conceded even by many of those who argue against the free-will defence in response to the problem of evil. God's 'vulnerability' could be interpreted as something like God's disappointment in or concern for evildoers.

As a result, for our purpose in this paper it can be concluded that eros - including both God's admiration for good persons and God's

${ }^{30}$ See Stump, Wandering in Darkness, pp. 122-3. 
desire for union with all of us - is a possible interpretation of an aspect of divine love. It is not then that God loves us solely agapeically. However, as I have noted, according to the union account of eros, the two conditions of personal presence and closeness must be fulfilled by human beings as well. And this is sufficient to block Schellenbeg's argument.

\section{REASSESSMENT OF SCHELLENBERG'S ARGUMENT}

In previous sections, I have accepted the idea that divine love has two main aspects, agape and eros; while agape is generous and unmotivated love, and involves benevolence, mercy, and compassion for all creatures regardless of their value, eros is attentive and responsive love, and involves liking, longing, admiration, and desire for union with the beloved. However, union with the beloved requires mutual closeness and personal presence. Mutual closeness and personal presence can be obtained only if the lover and the beloved do what is necessary for this. Then, the responsibility of human beings to respond to God's desire for union must necessitate not only his non-resistance to God but also his reflection on divine revelation, repentance, and praying.

Based on these premises, and by distinguishing eros and agape as two conceptions of divine love, I am now in a position to go through the formalization of Schellenberg's premise 1, first replacing love with eros, and then replacing love with agape, showing more formally than I have hitherto how the argument fails in both cases. Schellenberg's premise 1 can be summarized in the following statement:

$S(a)$ : If the loving God of theism exists, then, necessarily, His agapeic love ensures that all persons who are not resisting a relationship with Him will be in a position to participate in developing relationship with Him.

Obviously S(a) cannot be demonstrated, because God's love as agape does not necessarily entail any personal relationship whatsoever. Divine love as agape is like rain for all creatures: it falls on the just and unjust alike; it is not responsive to anything in the beloved and does not require any reciprocal relationship. If we accept agape as the interpretation of divine love it can straightforwardly be seen that Schellenberg's argument does not work. Of course, one may claim that divine agape necessitates divine eros in the sense that God, by His generous love toward all of us, bestows upon us what is required on our part to establish a relationship of reciprocal love with Him and to come into union with Him. One 
may thus expect that God, the perfectly loving, would provide us with whatever we need for our flourishing and growth toward our aim of union with Him, including the belief that He exists. But my answer to this is twofold. First, I suggest, there is an ambiguity in this sort of expectation. We should distinguish between two kinds of expectation we may have of God's agapeic love: one may expect God to provide human beings with whatever they need to reach their ultimate goal; or one may expect God to provide whatever they need to be in their ultimate good state. The former expectation - which considers God's purpose for the creation of human beings - is the only one that seems tenable, since it is a common claim of theists that God loves perfectly, but that God is also perfectly just and perfectly rational. God's love, then, would have to be calibrated to that degree compatible with the other properties essential to divine perfection. Divine love will not have the consequence the objector expects if that consequence is incompatible with divine rationality and justice. In theological terms, there is a venerable tradition which holds that grace is necessary for one to appreciate the evidence in support of theism, but (and this is an important but), grace is a divine gift of which justice precludes a universal distribution. God could give everybody the belief in His existence (as perhaps He did for angels); but His purpose for our creation is, perhaps, that He expects us to acquire this belief in other ways.

Second, and undeniably, the best sort of love respects the choices of its object. Thus, God, who is perfect in love, would prefer not to coerce us to return His love. Moreover, were God to override our wills in this regard, our love of Him would not be freely chosen. So God would prefer us to come to believe in Him and then reciprocate His love on our own.

We can see, then, that if we think of love in Schellenberg's argument as agape, his argument fails. By substituting eros for divine love in premise S we have:

$\mathrm{S}(\mathrm{e})$ : If the loving God of theism exists, then, necessarily, His eros ensures that all persons who are not resisting a relationship with Him will be in a position to participate in a developing relationship with Him.

My claim now is that even though it is in itself reasonable (contra Plato and Aristotle) to think of divine love as having an erotic element, S(e) cannot be defended. For whilst it is true that eros requires a reciprocal relationship, it is not the case that every normal human being who is non-resistant can be engaged in divine eros. If my argument is correct, 
it is not the case that only nonresistance or even non-culpability is sufficient for being engaged in union with God. One actually has to do something in addition, and not everyone who is nonresistant and nonculpable does do this thing - repent, pray, and reflect on revelation.

Therefore, Schellenberg's main premise is defeated.

\section{CONCLUSION}

Schellenberg argues that God does not exist because God's love requires a mutual relationship in which He cannot be hidden to those who are nonresistant, and yet it seems that God is hidden to some nonresistant nonbelievers. In this paper this argument is undermined by showing that God's love does not require that He be unhidden. If God's love is agape, God's love does not require Him to be unhidden from anyone. If His love is eros, it will only require Him to be unhidden from those who satisfy certain further conditions.

My objection was presented through an examination of Schellenberg's use of the notion of divine love in his argument. First, he uses the notion of divine love without paying sufficient attention to its different aspects and dimensions. Second, he ignores the point that it is the eros interpretation of divine love that requires reciprocal relationship, and that eros requires certain qualifications on the part of the creatures who are its object. Third, and most importantly, he treats the capability to have a relationship to God as a very simple capability that everybody who is capable of having normal human relationships possesses. He pays no attention to the sophisticated, long, and hard path of the mystical journey toward perfection that, in the history of mankind, only a very few men and women have properly traversed. ${ }^{31}$

${ }^{31}$ Thanks for wise counsel and penetrating comments to Muhammad Legenhausen, Tim Mawson, Mahmoud Morvarid, Richard Swinburne and Hamid Vahid. 